Policy Research Working Paper 2838

\title{
Ecoromic Mobility in Vietnam in the 1990s
}

\author{
Paul Glewwe \\ Phong Nguyen
}

The World Bank

Development Research Group

Macroeconomics and Growth

May 2002 


\begin{abstract}
Vietnam's high economic growth in the 1990s led to sharp reductions in poverty, yet over the same time period inequality increased. This increased inequality may be less worrisome if Vietnamese households experience a high degree of income mobility over time. This is because high mobility implies that the long-run distribution of income is more equally distributed than the short-run distribution, since some individuals or households are poor in some years, while others are poor in other years.
\end{abstract}

Glewwe and Nguyen examine economic mobility in Vietnam using recent household survey panel data. The problem of measurement error in the income variable, which exaggerates the degree of economic mobility, is directly addressed. Correcting for measurement error dramatically changes the results. At least one half of measured mobility is because of measurement error.

This paper-a product of Macroeconomics and Growth, Development Research Group-is part of a larger effort in the group to study household welfare and poverty reduction in Vietnam. Copies of the paper are available free from the World Bank, 1818 H Street NW, Washington, DC 20433. Please contact Emily Khine, room MC3-347, telephone 202-473-7471, fax 202-522-3518, email address kkhine@worldbank.org. Policy Research Working Papers are also posted on the Web at http://econ.worldbank.org. Paul Glewwe may be contacted at pglewwe@dept.agecon.umn.edu. May 2002. (26 pages)

The Policy Research Working Paper Series disseminates the findings of work in progress to encourage the exchange of ideas about development issues. An objective of the series is to get the findings out quickly, even if the presentations are less than fully polished. The papers carry the names of the authors and should be cited accordingly. The findings, interpretations, and conclusions expressed in this paper are entirely those of the authors. They do not necessarily represent the view of the World Bank, its Executive Directors, or the countries they represent. 


\title{
Economic Mobility in Vietnam in the 1990s
}

\author{
Paul Glewwe \\ University of Minnesota and the World Bank \\ Phong Nguyen \\ General Statistical Office, Vietnam
}

We would like to thank Gary Fields and Andrew Foster for useful discussion and comments. The findings, interpretations, and conclusions expressed in this paper are entirely those of the authors. They do not necessarily represent the views of the World Bank, its Executive Directors, or the countries they represent, nor do they necessarily represent the views of the General Statistical Office of Vietnam. 



\section{Introduction}

Vietnam enjoyed high rates of economic growth in the 1990's. One consequence of this growth was a remarkable decrease in the rate of poverty, from $58 \%$ of the population in $1992-93$ to $37 \%$ in $1997-98$ (General Statistical Office, 2000). Yet over the same time period inequality rose; the Gini coefficient of inequality for consumption expenditures increased from 0.330 to 0.354 . (In this paper we focus on consumption expenditures instead of income because expenditure data are, in general, more accurate; see Deaton and Grosh, 2000.) This suggests that wealthier Vietnamese households experienced greater increases in per capita consumption expenditures than did poorer households. Indeed, the per capita expenditures of the poorest $20 \%$ of the population was 854 thousand Dong in 1992-93 and 1099 in 1997-98 (both in 1998 prices), which implies an increase of $29 \%$, while the analogous figures for the wealthiest $20 \%$ of the population were 3911 and 6032, implying an increase of $54 \%$.

Yet the above picture depicting the consumption expenditures of the rich as growing at a much faster rate than the consumption expenditures of the poor is somewhat misleading. It is very unlikely that all of the households that were in the poorest $20 \%$ of the population in 1992-93 were again in the poorest $20 \%$ in 1997-98; some of them may have moved up into wealthier groups. This implies that if one looks at the same households in both years the households that were in the poorest $20 \%$ in $1992-93$ experienced a gain in consumption expenditures greater than $29 \%$. Similarly, some of the households that were in the top $20 \%$ in $1992-93$ almost certainly were no longer in that category by $1997-98$, so that looking at the same households would show growth in consumption expenditures of less than $54 \%$ among the wealthiest $20 \%$. 
The extent to which this movement of households' relative positions in the distribution of consumption expenditures tempers the above picture is an important policy question. Another way to think about this issue is note that the long-run distribution of consumption expenditures (and also of income) is more equally distributed than the short-run distribution if some individuals or households are poor in some years while others are poor in other years. Such economic mobility is a crucial aspect of the distribution of consumption expenditures, and how that distribution changes over time; this paper examines economic mobility in Vietnam in the 1990s.

Economic mobility is measured by comparing the incomes or expenditures of individuals or households over time. In practice, data are needed from a household survey that follows the same individuals or households over time. Recent examples of such studies are Fields and Ok (1999a), Gardiner and Hills (1999), Gottschalk (1997) and Maasoumi and Trede, 2001). A serious problem with any empirical work on economic mobility is that household income, and household expenditure, is likely to be measured with a large amount of error. This measurement error exaggerates the amount of inequality at a given point in time and also exaggerates the degree of economic mobility.

This paper uses estimation methods that minimize the bias caused by measurement error. It begins with a brief discussion of the measurement of economic mobility, and then shows how bias due to measurement error can be overcome in measures of mobility based on correlation of (functions of) individual or household income (or expenditure) over time. It then applies this method to a large panel data set from Vietnam, and finds that at least one half of measured mobility is due to measurement error. 


\section{Economic Mobility: Concepts and Measurement}

Economic mobility focuses on changes in an individual's or household's income over time. ${ }^{1}$ Yet the term "mobility" is often used in different ways. For example, an economy experiencing high economic growth that raises the incomes of all members may be characterized as having a large degree of mobility because everyone's income is increasing. However, there may be little change individuals' income shares at each point in time, so that people do not change their relative position in the distribution of income. In contrast, this paper is interested in mobility in terms of its potential to reduce inequality in the distribution of long-run income, which implies a focus on changes over time in the relative position of individuals or households in the distribution of income. This concept of mobility is often referred to as relative mobility.

The most common relative mobility measures are those based on correlation of functions of the income variable. Let $y_{1}$ be the distribution of income in time period 1 and let $y_{2}$ be the distribution of income for the same households or individuals in time period 2. The simplest mobility measure can be defined as $1-\rho\left(y_{1}, y_{2}\right)$, where $\rho\left(y_{1}, y_{2}\right)$ is the correlation coefficient of $y_{1}$ and $y_{2}$. (The correlation coefficient is the covariance of $y_{1}$ and $y_{2}$ divided by the standard deviation of $y_{1}$ and the standard deviations of $y_{2}$.) If incomes shares do not change at all between the two time periods, then $y_{1}$ and $y_{2}$ are perfectly correlated, so that $\rho\left(y_{1}, y_{2}\right)=1$ and the above mobility measure will be zero, signifying no mobility. In contrast, if $y_{1}$ and $y_{2}$ are completely uncorrelated, so that any

\footnotetext{
${ }^{1}$ Following the literature on the measurement of mobility, this section refers to households' incomes, rather than to their consumption expenditures. Yet everything in this section also applies to analyses based on household expenditures.
} 
given household's income in the first time period has no relationship at all to its income in the second time period, then $\rho\left(\mathrm{y}_{1}, \mathrm{y}_{2}\right)=0$ and the above mobility measure equals one, which can be thought of as "full" mobility.

Mobility measures based on the correlation coefficient range from 0 (no mobility) to 1 (full mobility); in almost data from any country, mobility will be somewhere between these two extremes. ${ }^{2}$ In fact, this approach to measuring mobility can be generalized to include correlation between (monotonic) transformations of the income variable at two points in time. For example, instead of examining the correlation between $y_{1}$ and $y_{2}$ one could used the correlation of the rank of $y_{1}$ and $y_{2}$, where the rank is one for the poorest person, two for the second poorest person, and so forth. Other mobility measures have been proposed using other transformations; for example the Hart (1981) index uses the correlation of the logarithm of $y_{1}$ and $y_{2}$. In this paper several transformations will be used to check the robustness of the findings. All of these mobility measures satisfy fundamental properties that a mobility index should have (see Glewwe, 2001, for details).

All mobility measures suffer from a serious problem; they exaggerate the extent of economic mobility when the income variable is measured with error. To see this problem, note that empirical studies of economic mobility typically use data from household surveys, which collect data on households' incomes and/or expenditures. Anyone who has observed how such data are collected understands that these variables are measured with error, in some cases with a large amount of error (see Deaton, 1997,

\footnotetext{
${ }^{2}$ In theory, negative correlation in incomes over time could exist; this would lead to mobility measures greater than one. But such a relationship, which would imply that households that are richer than average in the first time period would be poorer than average in the second time period, has never been found.
} 
and Deaton and Grosh, 2000). By definition, virtually any measure of mobility will overestimate true mobility because fluctuations in measured income that are purely due to measurement error are mistakenly interpreted as actual income fluctuations. The simplest example of this is the case of no mobility at all. By definition, actual mobility should be zero, but random measurement error in the data will show some (spurious) mobility and thus will increase measured mobility, exaggerating the extent of actual mobility.

This can be demonstrated more formally with mobility measures that are based on the correlation of functions of the income variable. Let $m\left(y_{1}, y_{2}\right)$ denote the simplest type of such a mobility measure; that is, $m\left(y_{1}, y_{2}\right)=1-\rho\left(y_{1}, y_{2}\right)$. The correlation coefficient is defined as:

$$
\rho\left(\mathrm{y}_{1}, \mathrm{y}_{2}\right)=\frac{\sigma_{y_{1}, y_{2}}}{\sqrt{\sigma_{y_{1}}^{2} \sigma_{y_{2}}^{2}}}=\frac{\sigma_{y_{1}, y_{2}}}{\sigma_{y_{1}} \sigma_{y_{2}}}
$$

where $\sigma_{\mathrm{y} 1, \mathrm{y} 2}$ indicates covariance and $\sigma_{\mathrm{y} 1}$ and $\sigma_{\mathrm{y} 2}$ indicate standard deviations.

If the measurement errors in the two time periods are uncorrelated with each other, $\rho\left(y_{1}, y_{2}\right)$ in equation (1) will be underestimated, implying that mobility (which equals $\left.1-\rho\left(y_{1}, y_{2}\right)\right)$ will be overestimated. More specifically, if random errors are added to $y_{1}$ and $y_{2}$, the numerator in equation (1) will be unchanged but the denominator will become larger:

$$
\rho_{m e}\left(y_{1}, y_{2}\right)=\frac{\sigma_{y_{1}, y_{2}}}{\sqrt{\left(\sigma_{y_{1}}^{2}+\sigma_{e_{1}}^{2}\right)\left(\sigma_{y_{2}}^{2}+\sigma_{e_{2}}^{2}\right)}}=\rho\left(y_{1}, y_{2}\right) \sqrt{\frac{\sigma_{y_{1}}^{2} \sigma_{y_{2}}^{2}}{\sigma_{y_{1}}^{2} \sigma_{y_{2}}^{2}+\sigma_{y_{1}}^{2} \sigma_{e_{2}}^{2}+\sigma_{e_{1}}^{2} \sigma_{y_{2}}^{2}+\sigma_{e_{1}}^{2} \sigma_{e_{2}}^{2}}}
$$


where $\rho_{\mathrm{me}}\left(\mathrm{y}_{1}, \mathrm{y}_{2}\right)$ is the observed correlation when measurement error is present and $e_{1}$ and $e_{2}$ are the random errors added to $y_{1}$ and $y_{2}$, respectively. Intuitively, these random errors add "noise" to $y_{1}$ and $y_{2}$. The larger the amount of noise, the less correlated will be $y_{1}$ and $y_{2}$, moving $\rho\left(y_{1}, y_{2}\right)$ closer to zero and increasing $m\left(y_{1}, y_{2}\right)$.

Fortunately, there is a simple way to estimate $\rho\left(y_{1}, y_{2}\right)$ that avoids measurement error bias. ${ }^{3}$ All one needs are instrumental variables that are correlated with $y_{1}$ and $y_{2}$ but uncorrelated with $e_{1}$ and $e_{2}$. To see this, recall that in a simple ordinary least squares (OLS) regression of a variable $x_{1}$ on a constant term and one other variable, call it $x_{2}$, the estimated coefficient for $\mathrm{x}_{2}$, call it $\mathrm{b}_{1 \mathrm{LS}}$, has a probability limit (plim) equal to $\sigma_{\mathrm{x} 1, \times 2} / \sigma_{\mathrm{x} 2}^{2}$. Similarly, a regression of $\mathrm{x}_{2}$ on $\mathrm{x}_{1}$ produces an estimated coefficient, call it $\mathrm{b}_{22 \mathrm{~s}}$, that has a plim equal to $\sigma_{\mathrm{x} 1, \mathrm{x} 2} / \sigma^{2}{ }_{\mathrm{x} 1}$. Thus, to estimate the correlation coefficient $\rho$ between $\mathrm{y}_{1}$ and $y_{2}$ one can regress $y_{1}$ on $y_{2}$ and $y_{2}$ on $y_{1}$ and then take the square root of the products of the associated coefficients:

$$
\left.\operatorname{plim} \mid \sqrt{b_{1 L S} b_{2 L S}}\right\rfloor=\rho\left(\mathrm{y}_{1}, \mathrm{y}_{2}\right)
$$

where $b_{1 L S}$ is the coefficient from an (OLS0 regression of $y_{1}$ on $y_{2}$ and $b_{2 L S}$ is the coefficient from An (OLS) regression of $y_{2}$ on $y_{1}$. Of course, if $b_{1 L S}$ and $b_{2 L S}$ are taken from simple OLS regressions, this estimate of $\rho\left(y_{1}, y_{2}\right)$ will still suffer from measurement error. However, one can use instrumental variables to correct for this measurement error

\footnotetext{
${ }^{3}$ The problem of measurement error and the use of instrumental variable methods to deal with it have been used in the literature on intergenerational mobility. See, for example, Solon (1992).
} 
(assuming credible instruments can be found) and then use the two $b_{L S}$ 's to obtain a consistent estimate of $\rho\left(y_{1}, y_{2}\right)$.

While this method to overcome bias due to measurement error works perfectly well in theory, finding suitable instrumental variables is not a simple task. Several problems that can arise. Consider estimation of $\rho\left(y_{1}, y_{2}\right)$ by means of instrumental variables (the same reasoning applies for correlation between transformations of $y_{1}$ and $y_{2}$ ). As explained above, if there were data on $y_{1}$ and $y_{2}$ without measurement error, one could consistently estimate $\rho\left(y_{1}, y_{2}\right)$ as the square root of the product of (the OLS estimates of) $\beta_{1}$ and $\beta_{2}$ from the following two regressions:

$$
\begin{aligned}
& \mathrm{y}_{1}^{*}=\alpha_{1}+\beta_{1} \mathrm{y}_{2}{ }^{*}+\mathrm{u}_{1} \\
& \mathrm{y}_{2}{ }^{*}=\alpha_{2}+\beta_{2} \mathrm{y}_{1}{ }^{*}+\mathrm{u}_{2}
\end{aligned}
$$

where asterisks denote variables that are measured without error. The $u$ terms are, by definition, uncorrelated with the regressors in each equation. Unfortunately, one never observes $\mathrm{y}_{1}{ }^{*}$ or $\mathrm{y}_{2}{ }^{*}$, but instead observes:

$$
\begin{aligned}
& y_{1}=y_{1}^{*}+e_{1}(6) \\
& y_{2}=y_{2}^{*}+e_{2}(7)
\end{aligned}
$$

where $y_{1}$ and $y_{2}$ denote observed values and $e_{1}$ and $e_{2}$ are measurement errors. Substituting (6) and (7) into (4) and (5) gives the following relationships between observed variables: 


$$
\begin{aligned}
& \mathrm{y}_{1}=\alpha_{1}+\beta_{1} \mathrm{y}_{2}+\mathrm{u}_{1}+\mathrm{e}_{1}-\beta_{1} \mathrm{e}_{2} \\
& \mathrm{y}_{2}=\alpha_{2}+\beta_{2} \mathrm{y}_{1}+\mathrm{u}_{2}+\mathrm{e}_{2}-\beta_{2} \mathrm{e}_{1}
\end{aligned}
$$

For equation (8), an instrumental variable is needed that is correlated with $\mathrm{y}_{2}{ }^{*}$ (and thus correlated with $y_{2}$ ) but uncorrelated with $u_{1}+e_{1}-\beta_{1} e_{2}$, and for equation (9) an instrument is needed that is correlated with $\mathrm{y}_{1}{ }^{*}$ (and thus with $\mathrm{y}_{1}$ ) but uncorrelated with $\mathrm{u}_{2}+\mathrm{e}_{2}$ $\beta_{2} e_{1}$

Turn to the requirement that the instrument for $y_{1}$, denoted as $z_{1}$, must be uncorrelated with $u_{2}+e_{2}-\beta_{2} e_{1}$. Consider an instrument for household per capita income or expenditure that has some causal relationship, such as the education of the head of household or land or capital stock. The first stage equations for $y_{1}{ }^{*}$ and $y_{2}{ }^{*}$ are:

$$
\begin{aligned}
& \mathrm{y}_{1}^{*}=\gamma_{1}+\delta_{1} \mathrm{z}_{1}+\mathrm{v}_{1} \\
& \mathrm{y}_{2}^{*}=\gamma_{2}+\delta_{2} \mathrm{z}_{2}+\mathrm{v}_{2}
\end{aligned}
$$

Even if such an instrumental variable is completely uncorrelated with the measurement error in $e_{1}$ and $e_{2}$, one can show that $z_{1}$ is uncorrelated with $u_{1}$ only if $\beta_{1} \delta_{2} \operatorname{Cov}\left(z_{1}, z_{2}\right)=$ $\delta_{1} \operatorname{Var}\left(z_{1}\right)$, where $z_{2}$ is the instrument for $y_{2}$. This is extremely unlikely to hold, as explained in Glewwe, 2001. A particularly interesting example is the case where $\mathrm{z}$ does not change over time, so that $z_{1}=z_{2}$; one can show that using this instrument will always yield a correlation coefficient of unity between $y_{1}$ and $y_{2}$ (see Glewwe, 2001).

This problem with causal variables as instruments implies that one should use "repeated measurements" of $y_{1}$ and $y_{2}$ as instrumental variables. For example, one could 
treat income and expenditure as two separate measurements (with error) of an underlying "standard of living" variable. Thus one could use income as an instrument for expenditures, and vice versa. Glewwe (2001) shows that the estimated correlation coefficient does not depend on which one is the instrument and which one is the instrumented variable, and that this method provides unbiased estimates of the correlation coefficient if the measurement errors at the same point in time across the two measurements are uncorrelated (one must also assume that measurement errors are not correlated over time across the two different types of measurement). If the measurement errors are positively correlated between the two different measurements at one point in time, IV estimates will overestimate mobility; if they are negatively correlated IV estimates will underestimate mobility.

To make these issues more concrete, consider lising income as an instrument for expenditures. This variable is constructed using different sections of the household questionnaire from Vietnam, so that random errors in recording data on the expenditure questions should have no effect on errors in recording data on the income questions. However, one can imagine circumstances where observed income (or any "repeated measurement" variable) is positively correlated with measurement error in the expenditure variable. For example, suppose that some survey respondents are worried that the interviewer is a tax collector in disguise. These respondents may underreport both income and expenditures, so that the measurement errors in observed incomes are positively correlated with measurement errors in the expenditure data. Another scenario is an interviewer that wants to finish the interview quickly. He or she may not ask probing questions about additional sources of income and additional types of expenditure, 
leading to the same problem. Finally, one can imagine situations where the respondent is not the person most knowledgeable about household income and expenditure (perhaps because the most knowledgeable person is temporarily away) and thus does not report some sources of income and expenditure.

To summarize, the above discussion suggests that any instrumental variable that has a "structural" or "causal" role may tend to underestimate mobility while an instrumental variable based on repeated measurements will tend to overestimate mobility. The ideal instrument would be a repeated measurement variable for which there is a good argument that its measurement errors are uncorrelated with those of the variable of interest. Anthropometric measurements, particularly those based on weight, are probably the best variables of that type. A final point is that when one has more than one instrumental variable, one can test the assumption that all the instruments are uncorrelated with the (composite) error term using a standard overidentification test (see Davidson and MacKinnon, 1993).

\section{Mobility in Vietnam in the 1990's}

A. Background and Data. Vietnam provides an excellent case for studying mobility. In the 1980's, it was one of the poorest countries in the world. During the 1990s, its high rate of GDP growth (8 percent) made it one of the most successful countries in reducing poverty and raising living standards, as explained in the introduction. The reasons for its success are currently under investigation. Despite these achievements, there is concern that the benefits of this economic growth are not being shared by all members of the population (World Bank, 1999). 
Another advantage of studying Vietnam is the availability of high quality panel data. The data used in this paper are taken from two households surveys conducted in the 1990s. The 1992-93 Vietnam Living Standards Survey (VNLSS) was conducted from October 1992 to October 1993, collecting data from 4800 households that comprise a nationally representative sample. The 1997-98 VNLSS was conducted from December 1997 to December 1998. It sampled 6000 households, including about 4300 of the households interviewed in the 1992-93 survey. Both surveys are patterned after the World Bank's Living Standards Measurement Study (LSMS) household surveys, which have been conducted in about 30 developing countries (see Grosh and Glewwe, 1998, 2000).

The two VNLSS surveys contain a large amount of data on many different topics. For a full description see World Bank $(1995,2000) .{ }^{4}$ The focus of this paper is on the overall economic welfare of households, particularly the mobility of household welfare over time. In both surveys, the indicator of economic welfare will be per capita household consumption expenditures. Although income data exist, they are likely to be less accurate than expenditures. More importantly, standard economic theory measures individual and household utility in terms of consumption expenditures, not income per se. However, income data can be useful. In particular, they can be used as an instrumental variable for per capita expenditures.

A final issue to address regarding the data is the number of households in the panel data set, and whether these households are a representative sample of Vietnamese households interviewed in 1992-93. This information is summarized in Table 1. Of the

\footnotetext{
${ }^{4}$ These documents can be downloaded from the website http://www.worldbank.org/lsms/lsmshome.html.
} 
original sample of 4800 households, all but $96(2.0 \%)$ were selected to be reinterviewed in 1997-98. (The 96 excluded households were all from the Red River Delta region they were excluded because the 1997-98 survey oversampled certain regions, and since the Red River Delta was not one of the oversampled regions fewer households were needed from it even though the sample size of the survey increased from 4800 to 6000 ). Of the 4704 selected households, 404 (8.4\%) were not reinterviewed in 1997-98. More specifically, interviewers were instructed to return to the dwelling that the household inhabited in the 1992-93 survey. If the household had moved within its village, interviewers attempted to find it and complete the interview. If the household moved outside of the village, no attempt was made to reinterview it. If some members moved while others remained in the original dwelling, the interview was done using all the current inhabitants of the original dwelling (both original members and "newcomers").

Thus, of the 4800 households interviewed in 1992-93, 4300 were reinterviewed in $1997-98$, which is a retention rate of $89.6 \%$. However, some of the households that remained may have rather tenuous links to the original household. First, one should probably exclude households for which the head has changed and the new head was not a member in the 1992-93 survey. Doing this eliminates 24 households, slightly reducing the retention rate to $89.1 \%$. The remaining 4276 households are the first sample used in this paper. A stricter definition of household retention would require that at least half of the individuals who were members in either 1992-93 or 1997-98 were members in both years. Doing this eliminates another 440 households, which leads to a retention rate of $79.9 \% .^{5}$ The remaining 3842 households are the second sample used in this paper.

\footnotetext{
${ }^{5}$ This retention rate includes six "natural cases" in which the number of household members present in both years was less than $50 \%$ of the individuals who were members in either year but no one moved in or
} 


\section{B. Measured Mobility without Correction for Measurement Error. By}

definition, mobility measures summarize in a single number the relationship between the distribution of income at two points in time. These numbers do not always have intuitive appeal, so it is also useful to start by depicting mobility in the form of transition matrices. Table 2 presents (relative) transition matrices for Vietnam from 1992-93 to 1997-98, using the VNLSS data. In each year households are grouped by quintiles (poorest $20 \%$, next poorest $20 \%$, etc. up to the wealthiest $20 \%$ ) to see how frequently they move across these groups. To check for robustness, both samples of panel households that were described above are used, one in which households are assumed to be the same if the head in one year was also a household member in the other year, and the other in which at least half of the individuals who were members in either 1992-93 or 1997-98 were members in both years.

The results appear to display a substantial amount of mobility. Only $41 \%$ of the population remained in the same quintile in the two years; about $40 \%$ moved up or down by one quintile and $19 \%$ moved up or down by two or more quintiles. These results are almost identical for the two samples. Thus, ignoring measurement error, one might conclude that the modest increase in inequality in Vietnam in the 1990's is not a major concern because low levels of household expenditures appear to be a temporary phenomenon for many households. In particular, about one half of the population that was in the poorest $20 \%$ of the population in $1992-93$ was no longer in that bottom quintile in 1997-98.

out of the household during the past five years because all changes were due to births or deaths. Examples are a household with 3 adults in 1992-93 where two had died by 1997-98, and a household with a married couple in 1992-93 who had had three children by 1997-98. 
How does this degree of mobility manifest itself in terms of mobility measures based on correlations of functions of the household expenditure variable? This is seen in Table 3. As long as incomes are not negatively correlated over time, correlations will lie between 0 (complete mobility in the sense that incomes in period 1 and period 2 are uncorrelated) and 1 (no mobility). Thus all mobility measures based on correlation of functions of the income variable will lie between 1 (complete mobility) and 0 (no mobility). The mobility measures in Table 3 range from 0.278 and 0.395 , which in general indicates substantial mobility although it is farther from complete mobility than from complete immobility.

The main point of Table 3 is to show how the mobility seen in the transition matrices of Table 2 is measured by these mobility indices. With one exception, the different mobility measures give similar results. Specifically, when one excludes the mobility index based on the correlation of the square of the income the indices range from 0.278 to 0.331 . The highest value, 0.395 , occurs for the mobility index based on squaring the income variable.

The mobility shown in Tables 2 and 3 is almost certainly overestimated because it ignores measurement error. This issue will be addressed in the next subsection, yet before doing so it is useful to demonstrate that the regression approach is in fact an alternative way to estimate the correlation coefficient. This is seen in Table 4 for the simple correlation coefficient. The first line shows the correlation coefficients for per capita expenditures in the two years for both samples of households, which is simply one minus the associated mobility index given in Table 3 . The second line shows (the OLS estimates of) the parameter $\beta_{2}$, the "slope" coefficient from a regression of $1992-93$ per 
capita expenditures on 1997-98 per capita expenditures and a constant term. The third line shows the estimate of $\beta_{1}$, the "slope" coefficient from a regression of 1992-93 per capita expenditures on 1997-98 per capita expenditures and a constant term. The fourth line demonstrates that the square root of the product of the estimates of these two coefficients yields the (estimated) correlation coefficient.

\section{Estimates of Mobility Corrected for Measurement Error. Once suitable} instrumental variables are found, estimates of $\beta_{1}$ and $\beta_{2}$ that are free of attenuation bias can be obtained, which can then be used to calculate mobility. This was done for the mobility index $1-\rho(x, y)$ for three different types of instrumental variables. The first instrumental variable is simply household income per capita. Household income is collected in a different part of the VNLSS questionnaire than the data used to calculate household expenditures, which reduces (but does not necessarily eliminate) the possibility that random errors in the reporting household expenditures spill over into the household income variable. Of course, household income is likely to be measured with random error as well, but as long as those errors are unrelated to the errors in the expenditure variable it is still a valid instrumental variable.

The first row of Table 5 shows estimates of economic mobility when per capita expenditures are instrumented using household income. As expected, the estimated mobility is much lower than the uncorrected estimates given in Table 3. The figures in brackets show the IV-corrected estimates as a percentage of the uncorrected estimates. This figure is $56.0 \%$ for the "head-same" sample and $53.8 \%$ for the " $50 \%$ threshold" sample. Recall from Section II that if measurement errors in income are likely to be positively correlated with measurement errors in expenditures, then these IV estimates 
will overestimate true mobility. This implies that these estimates can be thought of as upper bounds of the true amount of mobility. Thus nearly half, and perhaps even more than half, of the mobility shown in Table 3 is due to measurement error and is therefore spurious.

Because use of income as an instrumental variable is likely to overestimate mobility, it is useful to estimate mobility is using other plausible instrumental variables. One possibility is the ownership of basic durable goods, such as televisions, bicycles, motorcycles, vcrs and refrigerators. Households should make many fewer errors in reporting this information, relative to reporting their income. If they make no errors at all then there can be no correlation between errors in reported income and errors in the ownership of durable goods (because the latter type of error is always equal to zero).

Estimates of mobility that correct for measurement error by using the ownership of durable goods as instrumental variables are reported in the second row of Table 5. For both samples the reported mobility is even lower than when household income is used as an instrument. Specifically, mobility is estimated to be 0.102 for the "head same" sample and 0.118 for the " $50 \%$ threshold" sample. Taken at face value, these estimates suggest that almost two thirds of the observed mobility in Vietnam seen in Table 3 is purely due to measurement error in the expenditure variable.

Yet there are conceptual problems with durable goods as an instrumental variable. First, it is possible that some durable goods are forgotten altogether (or deliberately omitted) during the interview. This could cause positive correlation in the measurement errors of expenditures and of durable goods because the expenditure variable used here includes the estimated "use value" derived from the ownership of durable goods. Such 
correlation would lead to overestimation of mobility. Second, and more seriously, even if there were no measurement error in durable goods it is possible that this instrument is correlated with the u terms in equations (4) and (5). Because durable goods by definition last a long time, their production of "use value" in both time periods is similar to the impact of using causal variables as instruments. Thus these variables will tend to be positively correlated with the $u$ terms and thus will tend to underestimate true mobility.

The validity of durable goods as instrumental variables was checked using overidentification tests for the regressions corresponding to equations (4) and (5). This is possible because there were six durable goods used as instruments (color televisions, black and white televisions, bicycles, motorbikes, vcr's and refrigerators). The results are shown in the third and fourth rows of Table 5. The overidentification tests strongly reject the assumption that the instrumental variables are uncorrelated with the composite error terms in equations (6) and (7), so the estimates of mobility based on durable goods as instrumental variables must be discarded.

A final instrumental variable considered in this paper is the average body mass index (BMI) of adults age 18 and over. The VNLSS survey collected height and weight information from all household members. This can be used to calculate the BMI of each adult, which is defined as the weight of an individual (in kilograms) divided by the square of his or her height (in meters). Very simply, this indicates how "heavy" a person is given his or her height. Poorer individuals have leaner diets and thus are less heavy. The key advantage of BMI is that any measurement errors in it are extremely unlikely to be correlated with measurement errors in household expenditures. First, this information was not collected by the interviewer who filled out the household questionnaire but 
instead was filled out by a completely different survey team member. Second, none of the scenarios describing how income and expenditures may be correlated (such as households fearing tax collectors or interviewers wanting to finish the interview quickly) provide a coherent story as to why errors in the measurement of BMI should be correlated with errors in the measurement of household expenditures. On the other hand, there is a potential that BMI is correlated with the $u$ terms in equations (4) and (5). A "thin" person in 1992-93 may have a compromised ability to earn income not only in that year but also in future years, which implies that BMI in 1992-93 may have a direct causal relationship with household income and expenditures in 1997-98. This would lead to underestimation of the true amount of mobility.

The fifth row of Table 5 provides estimates of the mobility index $1-\rho\left(y_{1}, y_{2}\right)$ using household BMI (averaged over all adult household members) as an instrumental variable. Mobility is estimated at 0.121 for the "head same" sample and 0.101 for the "50\% threshold sample". As explained in the previous paragraph, this is a lower bound on true value of mobility. Combining it with the upper bound given when using per capita consumption as an instrumental variable, it seems that true mobility is somewhere between 0.34 and 0.56 of the mobility measured without correcting for measurement error.

As a final check on the regression results obtained from using household income and BMI as instrumental variables, both were used as instruments. The results are shown in the last three rows of Table 5. Predicted mobility is slightly lower than it was when income alone was used. More interestingly, because there are two instrumental variables one can test the exclusion restrictions using an overidentification test. In contrast to the 
case where durable goods were used, this specification easily passes the overidentification test in three of four cases, and in the fourth case the hypothesis that the instruments are no correlated with the compound error term can be rejected only at the $10 \%$ level. These estimates suggest that about one half of measured mobility is spurious, which implies that true mobility is much lower than seen in Tables 2 and 3.

\section{Conclusion}

Vietnam's rapid economic growth and relatively stable distribution of income suggest that all socioeconomic groups are benefiting from the booming Vietnamese economy. Moreover, simple calculations using panel data suggest that there is a large amount of economic mobility within Vietnam, which is appealing because it suggests that the long-run distribution of income is more equal than the distribution at any given point in time. However, such estimates of mobility may well overestimate true mobility because there is a large amount of measurement error in the data.

This paper applies a simple method to estimate economic mobility that corrects for bias caused by measurement error in the variable of interest. When applied to the data from Vietnam it shows that almost one half, and perhaps even more, of economic mobility is an artifact of measurement error and is thus illusory. This implies that Vietnam's worries about increasing inequality cannot be dismissed by pointing to high economic mobility, because such mobility is much lower than simple calculations suggest. Given the Vietnamese government's desire to minimize increases in inequality as economic growth continues, efforts to keep inequality from increasing must be on the forefront of the government's agenda. 


\section{References}

Davidson, Russell, and James MacKinnon. 1993. Estimation and Inference in Econometrics. Oxford University Press.

Deaton, Angus. 1997. The Analysis of Household Surveys: A Microeconomic Approach. Johns Hopkins University Press: Baltimore.

Deaton, Angus, and Margaret Grosh. 2000. "Consumption," in M. Grosh and P. Glewwe, eds., Designing Household Survey Questionnaires for Developing Countries: Lessons from 15 Years of the Living Standards Measurement Study. Oxford University Press: New York.

Fields, Gary, and Efe Ok. 1999. "Measuring Movement of Incomes." Economica 66: 455-471.

Gardiner, Karen, and John Hills. 1999. "Policy Implications of New Data on Economic Mobility." Economic Journal 109(453): F91-F111.

General Statistical Office. 2000. "Viet Nam Living Standards Survey 1997-98." Statistical Publishing House. Hanoi, Vietnam.

Glewwe, Paul. 2001. "How Much of Estimated Economic Mobility is Measurement Error? A Simple Method to Remove Measurement Error, with an Application to Vietnam". Department of Applied Economics. University of Minnesota.

Gottschalk, Peter. 1997. "Inequality, Income Growth and Mobility: The Basic Facts." Journal of Economic Perspectives, 11(2):21-40.

Grosh, Margaret, and Paul Glewwe. 1998. "Data Watch: The World Bank's Living Standards Measurement Study Household Surveys. Journal of Economic Perspectives.

Grosh, Margaret, and Paul Glewwe. 2000. Designing Household Survey Questionnaires for Developing Countries: Lessons from 15 Years of the Living Standards Measurement Study. Oxford University Press (for the World Bank).

Hart, Peter. 1981. "The Statics and Dynamics of Income Distributions: A Survey," in N. Klevmarken and J. Lybeck, eds., The Statics and Dynamics of Income. Tieto: Clevedon.

Maasoumi, Esfanidar, and Mark Trede. 2001. "Comparing Income Mobility in Germany and the United States Using Generalized Entropy Mobility Measures." Review of Economics and Statistics 83(3):551-559. 
Solon, Gary. 1992. "Intergenerational Income Mobility in the United States". American Economic Review. 82(3): 393-408.

World Bank. 1995. "Vietnam Living Standards Survey: Basic Information Document." Development Research Group. The World Bank, Washington, DC.

World Bank. 1999. "Vietnam: Attacking Poverty." East Asia Region. The World Bank, Washington, DC.

World Bank. 2000. "1997-98 Vietnam Living Standards Survey: Basic Information Document." Development Research Group. The World Bank, Washington, DC. 
1992-93 households

Excluded from 1997-98 survey

All household members moved

Remaining households

Among remaining Head is the same in both years 4300 households:

$\begin{array}{ll}\text { Households } & \text { Individuals } \\ 4800 & 23,839 \\ 96(2.0 \%) & 421(1.8 \%) \\ 404(8.4 \%) & 1,786(7.5 \%) \\ 4300(89.6 \%) & 21,632(90.7 \%)\end{array}$

$4276(89.1 \%) \quad 21,538(90.3)$

$3836(79.9 \%) \cdot 19,100(80.1)$

$3842(80.0) \quad 19,119(80.2)$

Notes:

1. The six natural cases refer to households in which no one moved in or out of the household in the past five years, but death or birth led to cases where the number of household members present in both years was less than $50 \%$ of the individuals who were members in either year. Examples are a household with 3 adults in 1992-93 of which two had died by 1997-98, and a household with a married couple in 1992-93 who had had three children by $1997-98$.

2. The figure of 19,119 includes individuals in panel households who joined in the household after 1992-93. When those individuals are excluded, the number of individuals who were members in the 3,842 households in both years is 17,459 , which is $74.5 \%$ of the individuals originally surveyed in all 4,800 households in 1992-93. 
Table 2: Transition Matrix for Vietnam: 1992-93 to $1997-98$

Head is the Same

Quintile

\begin{tabular}{|c|c|c|c|c|c|c|}
\hline \multirow[t]{2}{*}{ 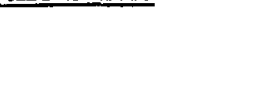 } & \multicolumn{5}{|c|}{ 1997-98 Quintile } & \multirow[b]{2}{*}{ Row Total } \\
\hline & 1 & 2 & 3 & 4 & 5 & \\
\hline 1 & $\begin{array}{l}2186 \\
(10.2 \%)\end{array}$ & $\begin{array}{l}1143 \\
(5.3 \%)\end{array}$ & $\begin{array}{l}689 \\
(3.2 \%)\end{array}$ & $\begin{array}{l}332 \\
(1.5 \%)\end{array}$ & $\begin{array}{l}45 \\
(0.20 \%)\end{array}$ & $\begin{array}{l}4395 \\
(20.4 \%)\end{array}$ \\
\hline 2 & $\begin{array}{l}1069 \\
(5.0 \%)\end{array}$ & $\begin{array}{l}1366 \\
(6.3 \%)\end{array}$ & $\begin{array}{l}1180 \\
(5.5 \%)\end{array}$ & $\begin{array}{l}615 \\
(2.9 \%)\end{array}$ & $\begin{array}{l}146 \\
(0.7 \%)\end{array}$ & $\begin{array}{l}436 \\
(20.3 \%)\end{array}$ \\
\hline 3 & $\begin{array}{l}501 \\
(2.3 \%)\end{array}$ & $\begin{array}{l}936 \\
(4.4 \%)\end{array}$ & $\begin{array}{l}1169 \\
(5.4 \%)\end{array}$ & $\begin{array}{l}1244 \\
(5.8 \%)\end{array}$ & $\begin{array}{l}501 \\
(2.3 \%)\end{array}$ & $\begin{array}{l}4351 \\
(20.2 \%)\end{array}$ \\
\hline 4 & $\begin{array}{l}163 \\
(0.8 \%)\end{array}$ & $\begin{array}{l}569 \\
(2.6 \%)\end{array}$ & $\begin{array}{l}1038 \\
(4.8 \%)\end{array}$ & $\begin{array}{l}1463 \\
(6.8 \%)\end{array}$ & $\begin{array}{l}1073 \\
(5.0 \%)\end{array}$ & $\begin{array}{l}4306 \\
(20.0 \%)\end{array}$ \\
\hline 5 & $\begin{array}{l}48 \\
(0.2 \%)\end{array}$ & $\begin{array}{l}148 \\
(0.7 \%)\end{array}$ & $\begin{array}{l}440 \\
(2.0 \%)\end{array}$ & $\begin{array}{l}929 \\
(4.3 \%)\end{array}$ & $\begin{array}{l}2536 \\
(11.8 \%)\end{array}$ & $\begin{array}{l}4101 \\
(19.1 \%)\end{array}$ \\
\hline Column Total & $\begin{array}{l}3967 \\
(18.4 \%)\end{array}$ & $\begin{array}{l}4162 \\
(19.3 \%)\end{array}$ & $\begin{array}{l}4516 \\
(21.0 \%)\end{array}$ & $\begin{array}{l}4583 \\
(21.3 \%)\end{array}$ & $\begin{array}{l}4301 \\
(20.0 \%)\end{array}$ & $\begin{array}{l}21,529 \\
(100.0 \%)\end{array}$ \\
\hline
\end{tabular}

$50 \%$ or more the Same

\begin{tabular}{llllllll}
\hline & & \multicolumn{6}{c}{$1997-98$ Quintile } \\
\cline { 3 - 7 } & 1 & 2007 & 1054 & 620 & 4 & 5 & Row Total \\
\cline { 3 - 7 } $1992-93$ & 242 & 33 & 3956 \\
Quintile & 2 & 909 & 1302 & $(3.3 \%)$ & $(1.3 \%)$ & $(0.2 \%)$ & $(20.7 \%)$ \\
& & $(4.8 \%)$ & $(6.8 \%)$ & $(5.7 \%)$ & $(3.0 \%)$ & $(0.6 \%)$ & $(20.8 \%)$ \\
& 3 & 463 & 874 & 1077 & 1127 & 402 & 3943 \\
& & $(2.4 \%)$ & $(4.6 \%)$ & $(5.6 \%)$ & $(5.9 \%)$ & $(2.1 \%)$ & $(20.6 \%)$ \\
& 4 & 131 & 492 & 924 & 1325 & 876 & 3748 \\
& & $(0.7 \%)$ & $(2.6 \%)$ & $(4.8 \%)$ & $(6.9 \%)$ & $(4.6 \%)$ & $(19.6 \%)$ \\
& 5 & 36 & 106 & 385 & 792 & 2160 & 3479 \\
& & $(0.2 \%)$ & $(0.6 \%)$ & $(2.0 \%)$ & $(4.2 \%)$ & $(11.3 \%)$ & $(18.2 \%)$ \\
& Column Total & 3546 & 3828 & 4092 & 4054 & 3584 & 19,104 \\
& & $(18.6 \%)$ & $(20.0 \%)$ & $(21.4 \%)$ & $(21.2 \%)$ & $(18.8 \%)$ & $(100.0 \%)$
\end{tabular}

Note: $\quad$ All numbers and percentages are in terms of individuals, not households. 
Table 3: Estimated Mobility, Ignoring Measurement Error

Mobility index

$1-\rho\left(y_{1}, y_{2}\right)$

$1-\rho\left(\sqrt{y_{1}}, \sqrt{y_{2}}\right)$

$1-\rho\left(y_{1}{ }^{2}, y_{2}{ }^{2}\right)$

$1-\rho\left(\operatorname{rank}\left(y_{1}\right), \operatorname{rank}\left(y_{2}\right)\right)$

$1-\rho\left(\ln \left(y_{1}\right), \ln \left(y_{2}\right)\right)$

Number of Households
Head same sample

0.309

$(0.011)$

0.292

$(0.011)$

0.395

(0.012)

0.331

$(0.011)$

0.298

(0.011)

4281
$50 \%$ threshold sample

0.299

$(0.012)$

0.278

$(0.011)$

0.394

(0.013)

0.316

$(0.012)$

0.282

$(0.011)$

3845

Note: Standard errors given in parenthesis. 
Table 4: Correlation Coefficients without Correction for Measurement Error

\begin{tabular}{|c|c|c|}
\hline & Head same sample & $50 \%$ Threshold Sample \\
\hline$\rho\left(y_{1}, y_{2}\right)$ & $\begin{array}{l}0.691 \\
(0.011)\end{array}$ & $\begin{array}{l}0.701 \\
(0.012)\end{array}$ \\
\hline$\beta_{2}$ (OLS) & $\begin{array}{l}0.315 \\
(0.013)\end{array}$ & $\begin{array}{l}0.327 \\
(0.015)\end{array}$ \\
\hline$\beta_{1}(\mathrm{OLS})$ & $\begin{array}{l}1.517 \\
(0.107)\end{array}$ & $\begin{array}{l}1.502 \\
(0.106)\end{array}$ \\
\hline$\sqrt{\beta_{1} \beta_{2}}(\mathrm{OLS})$ & $\begin{array}{l}0.691 \\
(0.028)\end{array}$ & $\begin{array}{l}0.701 \\
(0.029)\end{array}$ \\
\hline
\end{tabular}

(0.028) (0.029)

Notes: 1 . Standard errors for OLS estimates account for clustered sample design.

2. Standard errors for estimates of $\sqrt{\beta_{1} \beta_{2}}$ calculated using the delta method. 
Table 5: Estimated Mobility Using Three Kinds of Instrumental Variables

\section{Instrument Set}

Per capita Income:

$$
1-p\left(y_{1}, y_{2}\right)
$$

Durable Goods:

$$
\begin{array}{r}
1-\rho\left(y_{1}, y_{2}\right) \\
\chi^{2}(5) \text { tests } \\
\beta_{2}
\end{array}
$$$$
\beta_{1}
$$

Head Same Sample

$0.173[0.560]$

$0.102[0.330]$

$86.5^{* * *}$

$69.7^{* * *}$

$0.121[0.392]$

$0.167[0.553]$

0.4

2.6
50\% Threshold Sample

$0.161[0.538]$

0.118 [0.395]

$95.7 * * *$

$85.0 * * *$

Body Mass Index:

$$
1-\rho\left(y_{1}, y_{2}\right)
$$

Per Capita Income and Body

Mass Index:

$$
\begin{array}{r}
1-\rho\left(y_{1}, y_{2}\right) \\
\chi^{2}(1) \text { tests } \\
\beta_{2} \\
\beta_{1}
\end{array}
$$

0.4

$3.5^{*}$

* Significant at $10 \%$ level

** Significant at 5\% level

*** Significant at $1 \%$ level

Notes: 1. Numbers in brackets are the estimated mobility as a fraction of estimated (ignoring measurement error) given in Table 3. 


\begin{tabular}{|c|c|c|c|c|}
\hline & Title & Author & Date & $\begin{array}{l}\text { Contact } \\
\text { for paper }\end{array}$ \\
\hline WPS2820 & $\begin{array}{l}\text { The Privatization of the Russian } \\
\text { Coal Industry: Policies and Processes } \\
\text { in the Transformation of a Major } \\
\text { Industry }\end{array}$ & $\begin{array}{l}\text { Igor Artemiev } \\
\text { Michael Haney }\end{array}$ & April 2002 & $\begin{array}{l}\text { V. Joseph } \\
32155\end{array}$ \\
\hline WPS2821 & $\begin{array}{l}\text { Income, Wealth, and Socialization } \\
\text { in Argentina: Provocative Responses } \\
\text { from Individuals }\end{array}$ & Daniel Lederman & April 2002 & $\begin{array}{l}\text { P. Soto } \\
37892\end{array}$ \\
\hline WPS2822 & $\begin{array}{l}\text { An Econometric Analysis of the } \\
\text { International Bank for Reconstruction } \\
\text { and Development's Creditworthiness }\end{array}$ & David Mckenzie & April 2002 & $\begin{array}{l}\text { C. Mendoza } \\
80599\end{array}$ \\
\hline WPS2823 & $\begin{array}{l}\text { Real Exchange Rate Uncertainty } \\
\text { and Private Investment in Developing } \\
\text { Countries }\end{array}$ & Luis Servén & April 2002 & $\begin{array}{l}\text { P. Soto } \\
37892\end{array}$ \\
\hline WPS2824 & $\begin{array}{l}\text { Trade Policy and Labor Services: } \\
\text { Final Status Options for the West } \\
\text { Bank and Gaza }\end{array}$ & Maurice Schiff & April 2002 & $\begin{array}{l}\text { P. Flewitt } \\
32724\end{array}$ \\
\hline WPS2825 & $\begin{array}{l}\text { Demand for Imports in Venezuela: } \\
\text { A Structural Time Series Approach }\end{array}$ & Mario A. Cuevas & April 2002 & $\begin{array}{l}\text { M. Geller } \\
85155\end{array}$ \\
\hline WPS2826 & $\begin{array}{l}\text { Potential GDP Growth in Venezuela: } \\
\text { A Structural Time Series Approach }\end{array}$ & Mario A. Cuevas & April 2002 & $\begin{array}{l}\text { M. Geller } \\
85155\end{array}$ \\
\hline WPS2827 & $\begin{array}{l}\text { Learning to Export: Evidence from } \\
\text { Moroccan Manufacturing }\end{array}$ & $\begin{array}{l}\text { Marcel Fafchamps } \\
\text { Said El Hamine } \\
\text { Albert Zeufack }\end{array}$ & April 2002 & $\begin{array}{l}\text { E. Khine } \\
37471\end{array}$ \\
\hline WPS2828 & $\begin{array}{l}\text { Beyond Oaxaca-Blinder: Accounting } \\
\text { for Differences in Household Income } \\
\text { Distributions across Countries }\end{array}$ & $\begin{array}{l}\text { François Bourguignon } \\
\text { Francisco H. G. Ferreira } \\
\text { Phillippe G. Leite }\end{array}$ & April 2002 & $\begin{array}{l}\text { F. Bourguignon } \\
31056\end{array}$ \\
\hline WPS2829 & $\begin{array}{l}\text { The Spatial Distribution of Poverty } \\
\text { in Vietnam and the Potential for } \\
\text { Targeting }\end{array}$ & $\begin{array}{l}\text { Nicholas Minot } \\
\text { Bob Baulch }\end{array}$ & April 2002 & $\begin{array}{l}\text { R. Bonfield } \\
31248\end{array}$ \\
\hline WPS2830 & $\begin{array}{l}\text { Labor Market Implications of } \\
\text { Switching the Currency Peg in a } \\
\text { General Equilibrium Model for Lithuania }\end{array}$ & Lodovico Pizzati & April 2002 & $\begin{array}{l}\text { L. Pizzati } \\
32259\end{array}$ \\
\hline WPS2831 & $\begin{array}{l}\text { Health Outcomes in Poor Countries } \\
\text { and Policy Options: Empirical Findings } \\
\text { from Demographic and Health Surveys }\end{array}$ & Limin Wang & April 2002 & $\begin{array}{l}\text { L. Wang } \\
37596\end{array}$ \\
\hline WPS2832 & $\begin{array}{l}\text { Poverty and Survival Prospects } \\
\text { of Vietnamese Children under Doi Moi }\end{array}$ & $\begin{array}{l}\text { Adam Wagstaff } \\
\text { Nga Nguyet Nguyen }\end{array}$ & April 2002 & $\begin{array}{l}\text { H. Sladovich } \\
37698\end{array}$ \\
\hline WPS2833 & $\begin{array}{l}\text { School Choice, Student Performance, } \\
\text { and Teacher and School Characteristic } \\
\text { The Chilean Case }\end{array}$ & $\begin{array}{l}\text { Emiliana Vegas } \\
\text { cs: }\end{array}$ & April 2002 & $\begin{array}{l}\text { H. Sladovich } \\
37698\end{array}$ \\
\hline WPS2834 & $\begin{array}{l}\text { Investor Protection, Ownership, and } \\
\text { the Cost of Capital }\end{array}$ & $\begin{array}{l}\text { Charles P. Himmelberg } \\
\text { R. Glenn Hubbard } \\
\text { inessa Love }\end{array}$ & April 2002 & $\begin{array}{l}\text { K. Labrie } \\
31001\end{array}$ \\
\hline
\end{tabular}


Policy Research Working Paper Series

Title

WPS2835 A Decade of Fiscal Transition

WPS2836 Ethnic Minority Development in Vietnam: A Socioeconomic

Perspective

WPS2837 Reform, Growth, and Poverty in Vietnam
Author

Asad Alam

Mark Sundberg

Bob Baulch

Truong Thi Kim Chuyen

Dominique Haughton

Jonathan Haughton

David Dollar
Date

May 2002

May 2002

May 2002
Contact

for paper

A. Panton 85433

E. Khine

37471

E. Khine

37471 